\title{
EFFECT OF OKRA (Abelmoschus esculentus L.) FRUIT EXTRACT IN IMPROVING INSULIN SENSITIVITY BY MODIFYING GLUCOSE-REGULATING GENE EXPRESSION
}

\author{
W. Aligita ${ }^{1, *}$, S. Muhsinin ${ }^{1}$, K.T. Wijaya ${ }^{1}$, A. Artarini ${ }^{2}$ and I.K. Adnyana ${ }^{2}$ \\ ${ }^{1}$ Faculty of Pharmacy, Bhakti Kencana University, Bandung, Indonesia \\ ${ }^{2}$ School of Pharmacy, Bandung Institute of Technology, Bandung, Indonesia \\ *E-mail: widhya.aligita@bku.ac.id
}

\begin{abstract}
The previous study showed that okra fruit extract improved insulin sensitivity. Insulin resistance played an important role in the pathophysiology of type 2 diabetes. At the molecular level, impaired insulin sensitivity could be caused by several factors, mostly the occurrence of a mutation or posttranlation modification at the insulin receptor or its downstream effector molecule. This study aimed to evaluate the effect of okra fruit extract on glucose regulating gene expressions, such as PPAR- $\gamma$, adiponection, resistin, GLUT-4, and GLP- 1 gene. Evaluation of this gene expression was performed using the PCR-Gel Base method with the $\beta$-actin gene as an internal control gene. The area under the curve (AUC) from the image was determined by using ImageJ software. The results showed that the administration of metformin or okra fruit extracts affected the AUC value compared to the positive control, which meant that the expression of each gene changed. Increased expression occurred in PPARG, adiponectin, GLUT-4, and GLP-1 genes; while resistin gene expression decreased. It was concluded that okra fruit extract could improve insulin sensitivity by modifying the expression of PPAR- $\gamma$, adiponection, resistin, GLUT-4, and GLP-1 gene.
\end{abstract}

Keywords: Diabetes Mellitus, Abelmoschus esculentus L., Okra Fruit, Insulin Resistance, PPAR- $\gamma$

(C) RASĀYAN. All rights reserved

\section{INTRODUCTION}

Diabetes mellitus (DM) is a group of metabolic disorders characterized by hyperglycemia and abnormality of carbohydrate, fat and protein metabolism; caused by the inability of the pancreas to produce insulin or the body's inability to use insulin optimally. ${ }^{1,2}$

Okra (Abelmoschus esculentus (L.) Moench) is belonged to malvaceae family. The activity of okra fruit including antioxidant ${ }^{3,4}$, lipid inhibitor ${ }^{5}$, antidiabetic ${ }^{6,8}$, and glucose absorption inhibitor ${ }^{9}$ as well as a natural absorbent technology in water treatment. ${ }^{10}$

As an antidiabetic, okra fruit extract had a mechanism of action in increasing insulin secretion and sensitivity as well as inhibit glucose absorption in the gastrointestinal tract. ${ }^{8}$ The okra fruit extract contained steroids/triterpenoids and flavonoids. ${ }^{8}$ Another study showed that the okra fruit rich in $\alpha$ cellulose and hemicellulose, both belonged to the fiber group. And it was known that fiber could be so helpful to stabilize blood sugar level by suppressing sugar absorption in the intestinal tract ${ }^{9}$. Polyphenols compounds could modulate carbohydrate and lipid metabolism, reduce hyperglycemia, improve adipose tissue metabolism, dyslipidemia and insulin resistance, and stress-sensitive signaling pathways and alleviate oxidative stress and inflammatory processes. ${ }^{11}$ While triterpenoids had inhibited the formation of advanced glycation end products and strong antioxidant activity. ${ }^{12}$ Antioxidant activity of these compounds is also able to prevent the occurrence of metabolic syndrome. ${ }^{13}$

Decreased insulin sensitivity, also known as insulin resistance syndrome, plays an important role in type 2 diabetes pathophysiology, including its relationship with other symptoms of metabolic syndrome. Insulin resistance is usually associated with the inability of insulin to perform its function in glucose uptake,

Rasayan J. Chem., 13(1), 739-746(2020)

http://dx.doi.org/10.31788/RJC.2020.1315555

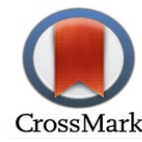




\section{RASĀYAN J. Chem. \\ Vol. 13 | No. 1 |739-746| January - March | 2020}

metabolism, and storage. ${ }^{14}$ At the molecular level, impaired insulin sensitivity can be caused by several factors, such as the occurrence of a mutation or posttranlation modification at the insulin receptor or its downstream effector molecule. ${ }^{15}$ Some of the glucose regulating genes include gamma-activated activator receptor peroxisome (PPAR- $\gamma$ ), resistin, GLP-1, GLUT-4, and adiponectin. Peroxisome Proliferator Activated Receptor-gamma (PPAR- $\gamma$ ), adiponectin, and resistin are known to play an important role in glucose transport ${ }^{16}$; GLP-1 in stimulating the hormone insulin in the pancreas; whereas GLUT-4 affect glucagon in regulating blood sugar levels. ${ }^{17,18}$

One of the insulin receptors that started to become the focus in the treatment of diabetes was PPAR$\gamma \cdot{ }^{19,20,21}$ PPAR- $\gamma$, belonged to the PPARs, is a nuclear hormone receptor that acted as a second messenger in regulating glucose uptake and utilization. PPARs consist of PPAR- $\alpha$, PPAR- $\delta$, and PPAR- $\gamma$. The primary effect of PPAR- $\alpha$ is to improve plasma lipid, PPAR- $\delta$ responsible for fatty acid oxidation and immunomodulator, while the PPAR- $\gamma$ improves insulin sensitivity. ${ }^{19,21}$ PPAR- $\gamma$ is highly expressed in fat tissue compared to muscle and liver. However, PPAR- $\gamma$ activation will increase insulin sensitivity in the muscle and liver by increasing adiponectin and decreasing resistin, leptin, interleukin and TNF- $\alpha$, and modifying fatty acid uptake and lipolysis, increasing glucose uptake in skeletal muscle and reducing hepatic glucose production and accumulation of liver fat. ${ }^{15,22}$

Adiponectin is a peptide hormone, mainly produced by adipocytes, plays a role in glucose regulation and catabolism of fatty acid. Adiponectin levels will increase when the body's fat decrease. Adiponectin level elevation improves insulin sensitivity because the serum adiponectin level has a positive correlation with insulin sensitivity. ${ }^{23}$ Resistin (resistant to insulin) is identified as having an association with obesity and insulin resistance. ${ }^{24}$ Increased expression of resistin in abdominal fat increases the risk of Type 2 diabetes associated with central obesity. ${ }^{25}$ The mechanism of resistin in causing insulin resistance is by inhibiting the insulin stimulated-glucose uptake and inhibiting the differentiation of adipose cells. ${ }^{26}$ Glucose uptake in muscles and adipose cells are determined by GLUT-4 expression. GLUT-4 is one of the glucose transporter present in muscle and adipose tissue and plays a role in insulin-mediated glucose uptake. ${ }^{27}$ GLUT-4 diffuses glucose into muscle and fat cells. GLUT-4 expression in skeletal muscle, heart, and fat cells has decreased in patients with insulin resistance. ${ }^{28}$ Another gene that plays a role in glucose regulation is GLP-1. GLP-1 is a polypeptide with a length of 30 amino acids produced in the endocrine part of intestinal epithelial L cells as a product of glucagon gene expression. GLP-1 is a powerful stimulant for insulin and glucagon inhibitors but is quickly converted into inactive metabolites by the DPP-4 enzyme.

The previous study evaluated the okra fruit extract in improving the insulin sensitivity ${ }^{8}$ The study was conducted by administrating okra fruit extract at various doses $(25,50,100$, and $200 \mathrm{mg} / \mathrm{kg} \mathrm{bw})$ to fat emulsion induced mice for 14 days. The parameter was the value of the insulin tolerance test constant $\left(\mathrm{C}_{\text {Ітт }}\right)$. The result showed a significant insulin sensitivity improvement in the group treated with okra fruit extract at a dose of 50 and $100 \mathrm{mg} / \mathrm{kg}$ bw, comparable to metformin as a standard drug. This current study aimed to evaluate the mechanism of action of the okra fruit extract on glucose regulating genes expression responsible in increasing insulin sensitivity.

\section{EXPERIMENTAL}

\section{Identification and Authentication of Plant Material}

Okra (Abelmoschus esculentus L.) fruit was purchased from Research Station for Spices and Medicinal Plants, Bogor, West Java, Indonesia and for its identification and authentication was performed by the Center for Plant Conservation Botanic Gardens, Bogor, West Java, Indonesia.

\section{Preparation of Abelmoschus esculentus L. Extract}

After cleaned and cut into pieces, okra fruit was mashed using a blender and the mixture was separated using a filter paper and the filtrate was collected and concentrated using a freeze drier.

\section{Animals}

Male Swiss-Webster mice 2-3 months old and weighing 20-30 g were kept at standard laboratory conditions at humidity $70-75 \%, 24-26^{\circ} \mathrm{C}$, and 12 hours light/dark cycle. Animals were fed with water $a d$ libitum and standard chow. The methods in this study were carried out by ethics and guide for animal 
RASĀYAN J. Chem.

Vol. 13 | No. 1 |739 - 746| January - March | 2020

care and used. Ethical approval was published by the Ethics Committee Padjajaran University (Registration number: 0818020269).

\section{General Procedure}

\section{Treatment of Insulin Resistance Animal Model}

There were two stages in antidiabetic testing in vivo. In the first stage, mice were induced using lipid emulsion $^{8}$ at a dose of $0.42 \mathrm{ml} / 20 \mathrm{~g}$ bw for 2 weeks. In the second stage, mice with insulin resistance (from first stage) were randomly grouped into 6 groups: standard drug group (metformin at dose of 135 $\mathrm{mg} / \mathrm{kg} \mathrm{bw}$ ), positive control group, and extract groups at dose of $25 \mathrm{mg} / \mathrm{kg} \mathrm{bw}, 50 \mathrm{mg} / \mathrm{kg} \mathrm{bw}, 100$ $\mathrm{mg} / \mathrm{kg}$, and $200 \mathrm{mg} / \mathrm{kg}$ bw. Administration of metformin and extracts was performed for 14 days. At the end of the study, mice were sacrificed and the adipose tissue and perirenal fat were collected to be evaluated the expression of the PPAR- $\gamma$ (perirenal fat), adiponectin (adipose tissue), resistin (perirenal fat), GLUT-4 (adipose tissue), and GLP1 gene (adipose tissue).

\section{Semi-Quantitative Gene Expression Evaluation}

Primers were derived from the resistin, GLUT-4, PPARG, adiponectin, and GLP1 genes (Table-1).

Table-1: Primers for the Genes

\begin{tabular}{|c|c|c|c|}
\hline Gene Name & Gene Code & Primer & Size (bp) \\
\hline \multirow[t]{2}{*}{ Adiponectin $^{29}$} & \multirow[t]{2}{*}{ Adipoq } & Adipoq F : 5'-AGCCT GGAGA AGCCG CTTAT-3' & \multirow[t]{2}{*}{151} \\
\hline & & Adipoq R : 5'-TTGCA GT AGA ACTTG CCAGT GC-3’ & \\
\hline \multirow[t]{2}{*}{ GLP-1R $\mathrm{R}^{30}$} & \multirow[t]{2}{*}{ glplr } & Glp-1r F : 5' - TCAGAGACGGTGCAGAAATG -3' & \multirow[t]{2}{*}{158} \\
\hline & & Glp-1r R : 5'- CAGCTGACATTCACGAAGGA-3' & \\
\hline \multirow[t]{2}{*}{ GLUT-4 ${ }^{31}$} & \multirow[t]{2}{*}{ slc2a4 } & slc2a4 F : 5'-CTGTGCCATCTTGATGACCGTG-3' & \multirow[t]{2}{*}{196} \\
\hline & & slc2a4 R : 5'-GTTGGAGAAACCAGCGACAGC-3' & \\
\hline \multirow[t]{2}{*}{ PPAR- $\gamma^{32}$} & \multirow[t]{2}{*}{ pparg } & Pparg F : 5'-CCACCAACTTCGGAATCAGCT-3' & \multirow[t]{2}{*}{434} \\
\hline & & Pparg R : 5' - TTTGTGGATCCGGCAGTTAAGA-3' & \\
\hline \multirow[t]{2}{*}{ Resistin $^{29}$} & \multirow[t]{2}{*}{ reth } & retn F : 5'-TCAAC TCCCT GTTTC CAAAT GC-3' & \multirow[t]{2}{*}{151} \\
\hline & & retn R : 5'-TCTTC ACGAA TGTCC CACGA-3' & \\
\hline
\end{tabular}

Primer quality was evaluated using the BLAST software (Basic Local Alignment Search Tool) through http://blast.ncbi.nlm.nih.gov/Blast.cgi. The alignment step was performed by using software (http://ncbi.nlm.nih.gov/tools/primer-blast/) by entering the nucleotide sequences. The next step was calculating the product length based on the forward and reverse primer used.

The expression of the genes at the mRNA level was carried out using the PCR gel base method with band thickness and area under the curve on the electropherogram as the parameters. Total RNA from each organ was isolated using SV Total RNA Isolation System kit. Cell breakdown was carried out by grinding each organ sample using mortar pestle and liquid nitrogen, then adding $175 \mu 1$ of RNA Lysis solution (particularly for liver used $350 \mu \mathrm{l}$ solution), $350 \mu \mathrm{l}$ RNA Dilution Buffer. The mixture was incubated at $70^{\circ} \mathrm{C}$ for 3 minutes, then centrifuged for 10 minutes at a speed of $13000 \mathrm{rpm}$. An $95 \%$ ethanol was added to the supernatant in the spin column as a precipitation process. Total RNA was washed using $600 \mu \mathrm{l}$ RNA wash solution and centrifuged for 1 minute at $13000 \mathrm{rpm}$. The next step was the removal of Genomic DNA by adding $40 \mu \mathrm{l}$ Yellow core buffer, MnCl $25 \mu \mathrm{l}$ and $5 \mu \mathrm{l}$ DNAse I enzyme and incubated at a temperature of $20-25^{\circ} \mathrm{C}$ for 15 minutes. The reaction was stopped by adding $200 \mu 1$ DNAse Stop Solution to the mixture. Total RNA was re-washed using $600 \mu \mathrm{l}$ and $250 \mu \mathrm{l}$ RNA wash solution and centrifuged for 2 minutes at a speed of $14500 \mathrm{rpm}$ at each step. Total RNA was eluted using $100 \mu \mathrm{l}$ Nuclease Free Water and centrifuged for 1 minute at $13000 \mathrm{rpm}$. The isolated total RNA could be stored in the elution tubes at a temperature of $-70^{\circ} \mathrm{C}$ (as an alternative could be stored at temperatures of -20 to $\left.30^{\circ} \mathrm{C}\right)$. 
RASĀYAN J. Chem.

Vol. 13 | No. 1 |739-746| January - March | 2020

The procedure of the RT-PCR method from isolated RNA was performed as stated in the AccessQuick TM RT-PCR System (Promega) kit protocol. The incubation temperature of RNA when transcripted into cDNA was $45^{\circ} \mathrm{C}$ for 45 minutes. The cDNA was then amplified by 35 cycles, including the initial denaturation stage at $95^{\circ} \mathrm{C}$ for 2 minutes then continued with annealing stage at $57^{\circ} \mathrm{C}$ for 30 seconds, Extention stage at $72^{\circ} \mathrm{C}$ for 30 seconds, and final extension at $72^{\circ} \mathrm{C}$ for 5 minutes. The amplification product was stored at $4^{\circ} \mathrm{C}$.

The amplification (amplicon) product was then detected using agarose gel electrophoresis. The electrophoresis process was run at 100 volts for 30 minutes. Electrophoregram was then visualized under planar UV and photographed using a camera with an ISO value 3200; E $\frac{1}{6}$; magnification $37.00 \mathrm{~mm}$; and $\mathrm{F} \frac{f}{5.6}$ using digiCam software. The area under the curve (AUC) from the image was determined using ImageJ software. ${ }^{33}$ This value interpreted the total gene expression and DNA in intact conditions because it was directly proportional to the band's thickness.

\section{RESULTS AND DISCUSSION}

The PCR technique can generally be used with certain modifications for gene analysis and the results can be directly applied. The success of a PCR process depends on the primer. The primers in the PCR process serve as a barrier to the target DNA fragment to be amplified (forward primer) and provide a hydroxy ($\mathrm{OH})$ group at the 3 'end that is required for DNA extension (reverse primer). The primer design was carried out based on known DNA sequences then evaluated the suitability of the nitrogen base sequence using the GenBank database system on the NCBI website. The primer obtained from the literature were then evaluated to see the primary quality using the BLAST software through http://ncbi.nlm.nih.gov/tools/primer-blast/. BLAST is a feature in NCBI which functions to analyze whether there are primary similarities between the primer used with genes in musculus on GenBank DNA and find out other nucleotide sequences that are similar to their primary sequence. The result showed that the primer sequence used specifically in the mus musculus was by the genes to be evaluated.

The AUC from the electropherogram was shown in Fig.-1. The results of the previous experiment showed that the administration of metformin or okra fruit extract increased insulin sensitivity ${ }^{8}$. In this current experiment, we will evaluate the effect of okra fruit extract in influencing the expression of PPARG, adiponectin, resistin, GLUT-4, and GLP1 genes. These genes play an important role in glucose regulation and determine the level of insulin sensitivity.

From Fig.-1, the positive control group showed reduced PPARG gene expression compared to the negative control group. This means that fat emulsion administration could reduce insulin sensitivity by inhibiting PPARG gene expression. Meanwhile, the group given metformin showed an increase in PPARG gene expression. The same results were also shown in the group given okra fruit extract. PPAR- $\gamma$ is found in high amounts in fat cells and a small portion in muscle cells such as adipose tissue. The activation of PPAR- $\gamma$ will stimulate the process of adipogenesis, differentiation and distribution of adipocytes so that it stimulates the efficiency of energy storage and mediates the metabolic effects of insulin and urges anti-inflammatory action. PPARG activation can also increase adiponectin and decrease resistin. Otherwise, in the condition of obesity or insulin resistance, reduction in PPARG expression will decrease adiponectin expression and an increase in resistin. This is consistent with the results of experiments that showed a decrease in adiponectin gene expression and an increase in resistin gene expression.

The adipoq gene that encodes adiponectin is an adipokin group that is usually expressed under certain conditions. Conditions that affect the level of adipoq gene expressions such as type 2 diabetes mellitus accompanied by insulin resistance and obesity. Adiponectin is present in adipose and plasma tissue, but in conditions of obesity, adiponectin can also be detected in the liver, pancreas and other fatty tissues such as perirenal tissue. ${ }^{34,35}$ Adiponectin expression has the opposite effect with other adipokines such as resistin and leptin. Adiponectin in a person with DM type 2 and obese conditions, will be lower than normal conditions (non-obese) or DM type 1. This gene has a role to prevent the occurrence of insulin resistance, especially in type $2 \mathrm{DM}$ by providing the effect of increasing insulin sensitivity. Adiponectin influences the process of gluconeogenesin in the liver, urging the effect of insulin sensitivity on skeletal 
RASĀYAN J. Chem.

Vol. 13 | No. 1 |739-746| January - March | 2020

muscles and the liver thereby increasing transport and burning of fatty acids. Increased burning of these fatty acids will also increase energy in skeletal muscles and cause a decrease in triglycerides in skeletal muscle and increase insulin transduction. ${ }^{36}$

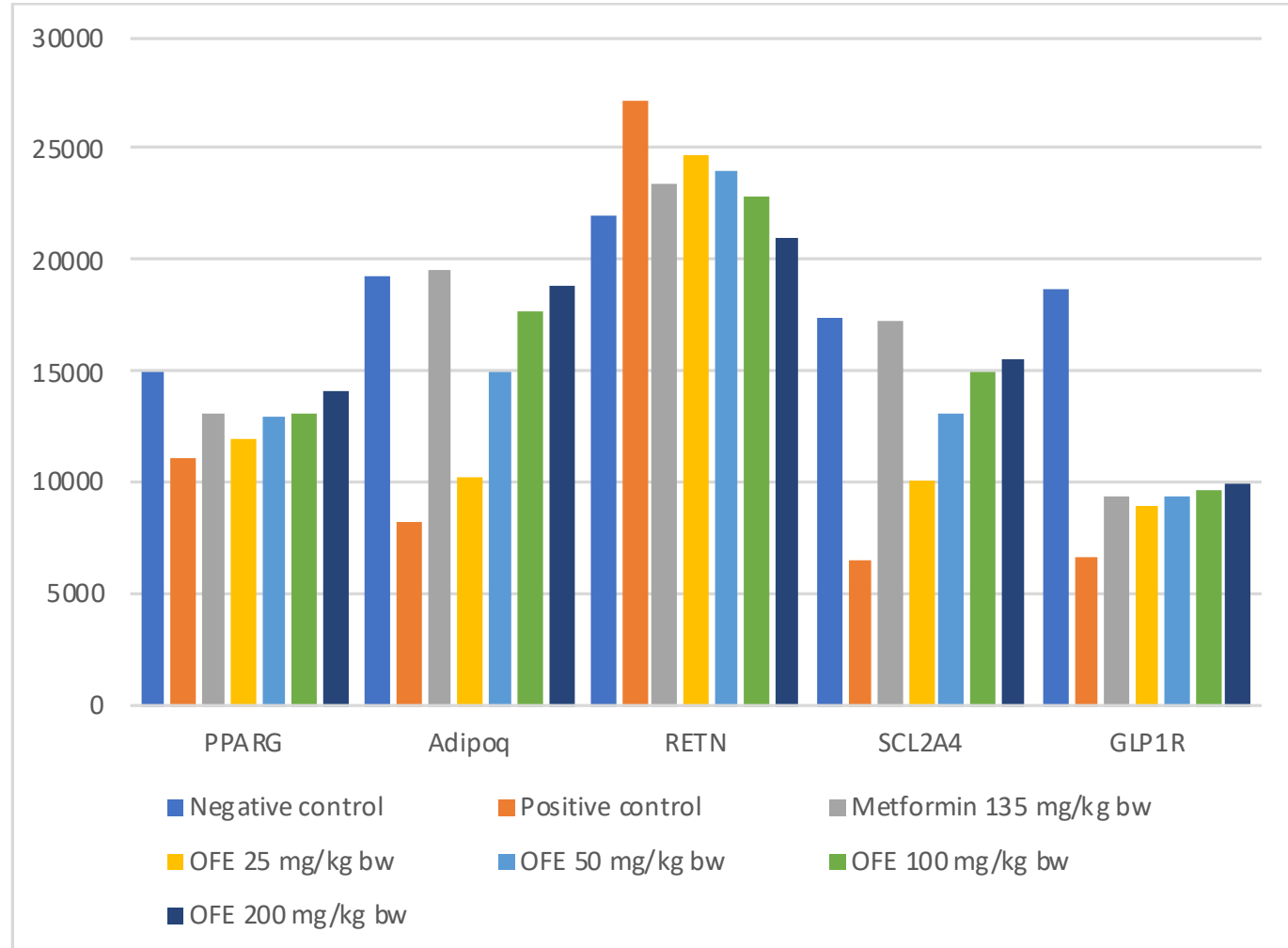

Fig.-1: AUC from Electrophoregram

Figure-1 showed the Adipoq gene in the positive control group had lower AUC compared to the negative control group and compared to the metformin and extract group. This means that the administration of fat emulsion caused a decrease in the expression of adiponectin, which in turn caused insulin resistance. Treatment with metformin or okra fruit extracts would increase the expression of the adiponectin gene so that it could improve insulin sensitivity.

Resistin expression is affected by PPARG activation. Resistin and other adipokines, such as leptin and TNF- $\alpha$, will generally increase in conditions of insulin resistance and obesity. ${ }^{36}$ This elevation in resistin expression will be associated with type $2 \mathrm{DM}$. The result showed that the positive control group experienced type 2 DM characterized by increased RETN gene expression. The difference in resistin expression could be seen in the treated groups. In the metformin and okra fruit extract groups, resistin expression decreased. This indicated that there was an improvement in insulin sensitivity in animal models. The results showed that there was a link between PPARG gene activation in its role in increasing adipoq gene expression and decreasing the expression of resistin genes.

GLUT-4 is an insulin receptor located on the surface of cell membranes, precisely in muscle and fat tissue. When insulin resistance occurs, GLUT-4 loses its stimulation to diffuse glucose into muscle cells, so in this condition, DM sufferers feel weak because there is no energy intake into the muscles. This is also influenced by decreased expression of the adiponectin gene. PPAR- $\gamma$ expression can stimulate the expression of GLUT-4. ${ }^{37}$ The results showed that the induction of high-fat emulsion was very influential on GLUT-4 gene expression, as well as treatment with metformin or extract. The positive control group showed lower GLUT-4 gene expression when compared to the negative control group. This means that GLUT4 gene expression reduction had a decreased effect on insulin sensitivity. Whereas in the group 
RASĀYAN J. Chem.

Vol. 13 | No. 1 |739 - 746| January - March | 2020

given treatment, both with metformin or okra fruit extract, it could be seen that an increase in GLUT4 gene expression also affected the improvement of insulin sensitivity.

GLP-1 is part of the hormone incretin which has a contribution to insulin release. Endocrine L cells of the intestinal epithelium produce GLP-1 as a product of glucagon gene expression and are stored in the pancreas and present in plasma. The expression of this gene will indirectly indicate the condition of the pancreas. A healthy pancreas will produce enough GLP-1 gene expression to stimulate insulin. Conversely, GLP-1 gene expression will decrease under DM conditions. This is related to the presence of the DPP-4 enzyme whose task is to convert GLP-1 into inactive metabolites, which causes a decrease in insulin release and increased release of glucagon so that glucose in the blood is not transported into cells. $^{38}$ The test results showed GLP1R gene expression on positive control was lower than the negative control, and the administration of metformin or okra fruit extracts could increase the expression of these genes. This showed that GLP1 gene expression reduction contributed to insulin resistance, and treatment using metformin or okra fruit extracts would increase GLP1 gene expression and in the end improve insulin sensitivity.

Based on experimental results, it was known that insulin resistance was largely determined by the expression of glucose-regulating genes. Administration of fat emulsion as an induction caused a decrease in insulin sensitivity characterized by a decrease in the insulin tolerance test constant $\left(\mathrm{C}_{\text {IтT }}\right){ }^{8}$ At the molecular level, reduction in insulin sensitivity was caused by changes in the expression of glucoseregulating genes, in this case, a decrease in PPARG, adiponectin, GLUT4, and GLP1 gene expression, and an increase in the expression of resistin genes. Metformin as the first line of type 2 DM therapy showed the effect of improving glucose metabolism and diabetes-related complications. However, the mechanism of action in detail is not fully understood. Physiologically, metformin can reduce hepatic glucose production. ${ }^{39}$ Molecularly, metformin can increase the expression of PPARG $^{40}$, adiponectin ${ }^{41}$, GLUT $-4^{37}$, GLP $1^{42}$, and decrease the expression of resistin genes ${ }^{43}$, as shown in Fig.-1. Similar results were also shown in the group administered okra fruit extracts; although in some genes, the changes given were not exactly like metformin. From Fig.-1, it could also be seen that increasing the dose caused an increase in the effect of affecting the expression of these genes.

\section{CONCLUSION}

Okra fruit extract improved insulin sensitivity in insulin resistance animals by increasing the expression of PPAR- $\gamma$, adiponectin, GLUT-4, and GLP-1; and reducing the expression of resistin gene.

\section{ACKNOWLEDGMENT}

The authors would like to thank The Ministry of Research, Technology, \& Higher Education Republic of Indonesia, for fully supporting this research, through the Research of Inter-university Cooperation scheme in 2019 .

\section{REFERENCES}

1. B. G. Wells, J. T. Dipiro, T.L.Schwinghammer, C. V. Dipiro, Pharmacotherapy Handbook. McGrawHill Education 2015.

2. American Diabetes Association, 38 (Suppl. 1), S8(2015), DOI:10.2337/dc15-S005

3. G. Shui and L.L. Peng, Journal of Chromatography, 1048, 17(2004), DOI: 10.1016/j.chroma.2004.07.032

4. S.E. Atawodi, J.C. Atawodi, G.A. Idakwo, B. Pfundstein, R. Haubner, G. Wurtel, Spiegelhalder and R.W. Owen, Journal of Medicinal Food, 12(6), 1316(2009), DOI:10.1089/jmf.2008.0211

5. N.M. Ansari, L. Houlihan, B. Hussain, A. Pieroni, Phytotherapy Research, 19(10), 907(2005), DOI: $10.1002 /$ ptr.1756

6. V. Sabitha, S. Ramachandran, K.R. Naveen, and K. Panneerselvam, Journal of Pharmacy and Bioallied Sciences., 3(3), 397(2011), DOI:10.4103/0975-7406.84447

7. N. Mishra, D. Kumar, S.I. Rizvi, Journal of Dietary Supplements, 13(6), 540, 634 (2016), DOI: $10.3109 / 19390211.2016 .1164787$

8. W. Aligita, S. Muhsinin, E. Susilawati, Dahlia, D.S. Pratiwi, D. Aprilliani, A. Artarini, I.K. Adnyana, Rasayan Journal of Chemistry, 12(1), 157(2019), DOI:10.31788/RJC.2019.1215059 


\section{RASĀYAN J. Chem. \\ Vol. 13 | No. 1 |739 - 746| January - March | 2020}

9. E. Abi, I. Abi, \& M.J. Ladan, Endocrinology and Diabetes Research Journal, 3(1), (2017), DOI: $10.4172 / 2470-7570.1000118$

10. S. Ramesh, J.S. Sudarsan, M. Jothilingam, Rasayan Journal of Chemistry, 9(3), 325(2016)

11. R. Testa, A.R. Bonfigli, S. Genovese, V.D. Nigris, \& A. Ceriello, Nutrients, 8(5), 310 (2016), DOI: $10.3390 /$ nu 8050310

12. J. Nazaruk \& M. Borzym-Kluczyk, Phytochemistry Reviews, 14(4), 675(2015), DOI:10.1007/s11101-014-9369-X

13. G. Haro, I. Iksen, R.M. Rumanti, N. Marbun, R.P. Sari, R.P.J. Gultom, Rasayan Journal of Chemistry, 11(1), 232(2018), DOI: 10.7324/RJC.2018.1112011

14. B.B. Kahn \& J.S. Flier, The Journal of Clinical Investigation, 106(4), 473(2000), DOI: $10.1172 / \mathrm{JCI} 10842$

15. O. Pedersen, J.F. Bak, P.H. Andersen, S. Lund, D.E. Moller, J.S. Flier, B.B. Kahn, Diabetes, 39, 865(1990), DOI:10.2337/diab.39.7.865

16. P.M. Kumar, M.V. Venkataranganna, K. Manjunath, G.L. Viswanatha and G. Ashok, Journal of Intercultural Ethnopharmacology, 5(2), 146(2016), DOI:10.5455/jice.20160224051727.

17. A.E. Civitarese, C.P. Jenkinson, D. Richardson, M. Bajaj, K. Cusi, S. Kashyap, R. Berria, R. Belfort, R.A. DeFronzo, L.J. Mandarino and E. Ravussin, Diabetologia, 47(5), 816(2004), DOI: $10.1007 / \mathrm{s} 00125-004-1359-\mathrm{x}$

18. D. Le Roith \& Y. Zick, Diabetes Care, 24(3), 588(2001), DOI:10.2337/diacare.24.3.588

19. M.B. Wright, M. Bortolini, M. Tadayyon, \& M. Bopst, Molecular Endocrinology, 28(11), 1756(2014), DOI: 10.1210/me.2013-1427

20. R. Rios-Vazquez, R. Marzoa-Rivas, I. Gil-Ortega and J.C. Kaski, American Journal of Cardiovascular Drugs, 6(4), 231(2006), DOI:10.2165/00129784-200606040-00003

21. J.P. Wilding, Diabetes, Obesity, and Metabolism, 14(11), 973(2012), DOI:10.1111/j.14631326.2012.01601.x

22. U. Meier, Clinical Chemistry, 50, 1511(2004), DOI:10.1373/clinchem.2004.032482

23. G. Litwack: Adiponectin Volume 90 of Vitamins and Hormone. Academic Press 2012.

24. J. Chen, L. Wang, Y.S. Boeg, B. Xia and J.J. Wang, Endocrinology, 175(2), 499(2002), DOI: $10.1677 /$ joe. 0.1750499

25. C. McTernan, P. McTernan, A. Harte, P. Levick, A. Barnett and S. Kumar, The Lancet, 359, 46(2002), DOI:10.1016/S0140-6736(02)07281-1

26. E.E. Kershaw \& J.S. Flier, Journal of Clinical Endocrinology and Metabolism, 89(6), 2548(2000), DOI: $10.1210 /$ jc. $2004-0395$

27. Martini and Frederic: Fundamentals of Anatomy and Physiology 90th ed. Pearson Education Inc 2012.

28. P.R. Sheperd and B.B. Kahn, The New England Journal of Medicine, 341(4), 248(1999), DOI: 10.1056/NEJM199907223410406

29. S.K. Park, S.Y. Oh, M.Y. Lee, S. Yoon, K.S. Kim and J.W. Kim, Diabetes, 53(11), 2757(2004), DOI: $10.2337 /$ diabetes.53.11.2757

30. L.Bai, G. Meredith and B.E. Tuch, The Journal of Endocrinology, 186(2), 343(2005), DOI: $10.1677 /$ joe. 1.06078

31. D. Furuya, A.C. Poletto, H.S. Freitas and U.F. Machado, Journal of Molecular Endocrinology, 49(2), 97(2012), DOI:10.1530/JME-12-0037

32. M.Inoue, T. Ohtake, W. Motomura, N. Takahashi, Y. Hosoki, S. Miyoshi, Y. Suzuki, H. Saito, Y. Kohgo and T. Okumura, Biochemical Biophysical Research Communications, 336(1), 215(2005), DOI: $10.1016 /$ j.bbrc. 2005.08 .070

33. D.A. Hewajuli and N.L. Dharmayanti, Indonesian Bulletin of Animal and Veterinary Sciences, 24(1), 16(2014), DOI:10.14334/wartazoa.v24i1.1022.

34. M.Boyraz, F. Cekmez, A. Karaoglu, P. Cinaz, M. Durak, A. Bideci, Biomarkers in Medicine, 7(5), 737(2013), DOI:10.2217/bmm.13.13

35. A.A. Gumbs, Obesitiy Surgery, 18(9), 1183(2008), DOI:10.1007/s11695-008-9599-3 
RASĀYAN J. Chem.

Vol. 13 | No. 1 |739 - 746| January - March | 2020

36. J. Chen, H. Zhao, X. Ma, Y. Zhang, S. Lu, Y. Wang, C Zong, D. Qin, Y. Wang, Y. Yingfeng Yang, $\mathrm{X}$. Wang and Y. Liu, Cellular Physiology and Biochemistry, 42(3), 1165(2017), DOI: $10.1159 / 000478872$

37. Z. Wu, Y. Xie, R.F. Morrison, N.L. Bucher, S.R. Farmer, Journal of Clinical Investigation, 101(1), 22(1998), DOI:10.1172/JCI1244

38. M.A. Nauck, I. Vardarli, C.F. Deacon, J.J. Holst, J.J. Meier, Diabetologia, 54(1), 10(2011), DOI: 10.1007/s00125-010-1896-4

39. G. Rena, D.G. Hardie, E.R.P. Pearson, Diabetologia, 60(9), 1577(2017), DOI:10.1007/s00125-0174342-z

40. E.M. Elia, C. Pustovrh, S. Amalfi, L. Devoto, A.B. Motta, Fertility and Sterility, 95(8), 2534(2011), DOI: $10.1016 /$ j.fertnstert.2011.02.004

41. G. Basios, E. Trakakis, Ch. Chrelias, P. Panagopoulos, V. Vaggopoulos, P. Skarpas, D. Kassanos, G. Trimidiadis, E. Hatziagelaki, Gynecological Endocrinology, 31(2), 136(2015), DOI: 10.3109/09513590.2014.975684

42. E. Bahne, E.W.L. Sun, R.L. Young, M. Hansen, D.P. Sonne, J.S. Hansen, U. Rohde, A.P. Liou, M.L. Jackson, D. de Fontgallant, P. Rabbit, P. Hollington, L. Sposato, S. Due, D.A. Wattchow, J.F. Rehfeld, J.J. Holst, D.J. Keating, T. Vilsboll, F.K. Knop, Journal of Clinical Investigation (JCI) Insight, 3(23), (2018), DOI:10.1172/jci.insight.93936

43. H.Fujita, H. Fujishima, T. Morii, J. Joshimura, M. Kakei, S. Ito, Biochemical and Biophysiological Research and Communications, 298(3), 345(200), DOI:10.1016/s0006-291x(02)02464-6

[RJC-5555/2019] 